\title{
Thomas Hobbes Hayatı, eserleri ve Hukukî Fikirleri (*)
}

Yazan Asistan Yahya Zabunoğlu

\author{
X-) Yemin mükellefigete hig birşey ilâve \\ et mez.
}

Hobbes, evvelce de belirttiğimiz üzere, yalnızca sözlerin bağlayıcı olmak bakımından bir değer ifade etmediği hususunda israr eder (54) : «... sözlerin kuvveti, fertleri, tanzim ettikleri mukavelelerden doğan vecibelerini ifaya zorlamak bakımından, zayıftır» (55). Yine Hobbes'a nazaran, bu zayıflığ bertaraf eden belli bașlı iki saik mevcuttur: Sözünü tutmamadan doğan korku ve vadini yerine getirmeme. ye lüzum görmemekten neș'et eden gurur veya tefahür. Yine Hobbes'a göre bu sonuncusu, tahmin edildiğinden daha az bulunan bir cömertliktir: hele, zenginlik, mevki ve hissi zevkler peșinde koșanlarda hiç bulunmaz; ama bunların peșinde koșanlar, insanlığın büyük kısmunı teşkil ederler. Iște böylece medeni cemiyetten evvel veya bu cemiyetin harpler vasıtasiyle inkitaa uğradığı zamanlarda, tamah, hırs, şehvet ve diğer kuvvetli arzularm aldatması veya teșviki ile insanların meydana getirdikleri mukavelelerin kuvvet ve muteberiyet kazanabilmesi ve bunu devam ettirebilmesine imkân yoktur. Bu bakimdan tek müessir unsur Allah korkusu idi ve mukavelelere yeminler ilâve edilmek suretiyle, ifada bulunmayacak tarafın Allah'ın gazabına uğrayacağı kaydediliyordu. Hobbes bu yemin formüllerinden misâller verir (56) ve yemin ile mükellefiyet arasındaki rabitanın mahiyetini açlklayıp, yeminin sadece mükellefiyetin veya ifanın yerine getirilmesini teminde rolü olan bu bir unsur olduğunu kaydettikten sonra șöyle der: "Yemin, mükellefiyete bir șey ilâve etmez görünüyor; çünkü bir mukavele yemin olmaksızın da Allah'ın nazarında hukukîdir; muteberdir ve bağlayıcıdır. Eğer gayri hukukî ise, zaten kimseyi bağlamaz ve bir yeminle teyid edilmiș olmasınun bu duruma bir tesiri olmaz.»

\footnotetext{
(*) Baş kısmı Fak. Der. C. : XIV, s. : 1 - 2, de.

(53) Leviathan... Sf. : 92.

(54) Bakiniz Sf. 92.

(55) Leviathan... Sf. 92.

(56) Bakiniz: Leviathan... Sf. : 93.
} 
6. - DIGER TA- Hobbes, Leviathan'in XV. kesiminde «diğer tabiî BIÎ KANUNLAR kanunlardan» bahseder; ilk ele aldığı ve diğerlerine nazaran daha etraflı incelediği adalet veya hakkaniyettir. Bu kesimde Hobbes'un adalet ile ahde vefa kaidesini kastettiği anlașlmaktadir.

\section{A-) Uçücii tabiat kanunu adalet: (57)}

«.... bahsettiğimiz kanurları (birinci ve ikinci tabî̂ kanunlar) bir üçüncüsü takip eder: Insanların meydana getirdikleri mukavelelerin hükümlerini yerine getirmeleri...».

a) «Adalet» ve «adaletsizlik» ne dir?

«Ve bu tabiat kanununda (yani insanlarm meydana getirdikleri mukavelelerin hükümlerine riayet etmeleri suretindeki kanund $r$ ) ADALET'in menșei ve aslı mündemiçtir. Hiç bir mukavele bulunmadiğı zaman, yani tabiat halinde, intikal ettirilmiş bir hak da yoktu ve herkesin herșey üzerinde hakkı vardı ve neticeten hiçbir hareket adalete aykırı değildi. Fakat bir mukavele yapıldığ onu ihlâl etmek adalete aykırıdır. Ve ADALETSİZLIK'in tarifi mukavelenin hükümlerine uymamak, ondan tahaddüs eden mükellefiyeti ifa etmemekden bașka birșey değildir. Ve herhangi bir surette adalete aykırı olmayan șey, adalete uygun yani «meșrûdur».

b) «Adalet» ve «mülkiyet», devletin teessüsü ile bașlar. (58).

«Fakat mukaveleler karşılıklı itimadı gerektirdiği için, taraflardan birinin mukaveleden doğan mükellefiyetini yerine getirmiyeceği korkusu mevcut bulunduğunda, daha evvelki kesimde söylendiği gibi, mukaveleler de gayri muteberdir.; ADALET, menșei itibariyle mukavelelerin inikadı sırasında bahis konusu olmasina rağmen bu böyledir... Bu sebebten dolayı, hakkaniyete yani adalete aykırı ve uygun mefhumları ortaya çıkmadan evvel, mukaveleye aykurı hareket ettikleri takdirde elde edebilecekleri menfaattan daha büyük olan ceza korkusu ile fertleri eșit olarak giriștikleri mukavelelerin gerektirdiği mükellefiyetleri ifaya mecbur edecek zorlu bir kuơret mevcut olmalıdır. Ve bir șeyin mülkiyet mevzuu haline gelmesi jçinde bir kudrete ihtiyaç vardır: bu kudret de devletin teessüsünden evvel mevcut değildir. Ve keza bu Mekteplerin alelâde adalet tariflerinden de istihraç edilir : Hakkaniyet veya adalet, herkese kendisi ne ait olanı veren daimi bir iradedir (Justice is the constant will of

(57) Leviathan... Sf. 93.

(58) Leviathan... Sf. 94. 
giving to every man his own). Ve bu sebepten aidiyyet olmayan yerde mülkiyet de yoktur. Herkesin herșey üzerine hakkı olduğu yerde mülkiyet de yoktur; adalete aykirı da yoktur. Ve her nerede zecrî bir kudret tesis edilmemişse, ki bu devlet kurulmamış demektir, mülkiyet de yoktur. Herkesin herşey üzerinde hakkı olduğu yerde devlet de yoktur; hiç bir șey de hakkaniyete yani adalete aykırı değildir. Böylece hakkaniyet, mahiyeti itibariyle, muteber mukavelelere riayette mündemiçtir; fakat mukavelelerin muteberiyeti, fertleri mukaveleye riayete icbar edecek yeterlikte bir «civil» kudret teessüs etmedikçe bahis konusu olamaz. Bu suretle, mülkiyet dahi bu «civil» kudret teessüs etmedikçe bahis konusu olamaz.»

c) Hakkaniyet akla aykırı değildir (59).

Hobbes, aptalın birinin aklına adalet diye bir șey olmryacağı yolunda bir fikrin gelebileceğini hatta onun bu fikri açıkça ifade edebileceğini, mukavelenin inikadında tarafm kendi menfaati üzere hareketi nazara alınırsa, yine menfaat uğruna mukavelenin hükmünü yerine getirmenin veya getirmemenin akla aykırı hiç bir tarafı olmadığını ileri sürülebileceğini söylüyor ve buna benzer akla gelebilecek sair mütalậaları ilâve ediyor; müellife göre bu yolda düșünmek, hiç șüphesiz yanlışdır; hatalıdır.

Hobbes'a göre hakkaniyetin akla aykurı olup olmayacağı meselesinin karșllklı söz vermeler, vaatte bulunmalar halinde yeri yoktur; buna mukabil «... vaatte bulunan tarafların üstünde bir kudretin bulunmadığı halde, mukavele de yoktur ki böyle bir kudretin mevcut olmaması, her iki taraf için de ifa emniyetinin yokluğu demektedir; fakat, taraflardan birisi zaten ifade bulunmușsa veya onu ifada bulunmaya zorlayacak bir kudret mevcut ise, işte bu halde ortaya bu ifanın akla aykırı olup olmadığı meselesi çıkar ki bu, diğer tarafın ifa edip etmemesinin kendi menfaatine aykirı olup olmaması demektir. Ve ben derimki bu akla aykırı değildir..»

d) Hükümrana karșı isyana kalkıșmak akla aykırıdır (60).

Hobbes, hakkaniyet ve adalet ile akıl arasmdaki münasebeti incelerken hükümrana karșı isyanın mahiyetine de dokunmaktadır. O'na göre, hükümrana karșı isyana teșebbüs etmek, beklenilen, makul bir hareket değildir; bilâkis akla aykırıdır. Ưstelik başkalarına da aynı surette isyan veya itaatsizlik teșebbüsünde bulunmakta örneklik

(59) Leviathan... Sf. 94-95.

(60) Levathan... Sf. 96. 
edilmiș olur. Demekki hakkaniyet, mukaveleye riayettir ve bu aklin bir kaidesidir ki, böylece biz, hayatımız ve neticeten tabî̀ kanun için tahripkâr olan herhangi bir şeyi yapmaktan men'ediliriz.

e) Uhrevî otoriyete karși gelme (61).

Hobbes, hükümrana karșı isyana kalkıșmanın akla aykırı olduğunu belirttikten sonra, uhrevî otoriteye karșı gelme meselesine temas eder ve der ki, «... ferdin öldükten sonraki durumu hakkında hiçbir tabiî malûmata sahip bulunmadığımız için... bir imanın jhlâli aklın bir kaidesinin veya bir tabiî kanunun ihlâli sayılmaz.» Cok muhtemelki, bu ve benzeri fiikirleri yüzünden Kilise, Hobbes'a karșl cephe almıstır.

f) Insanlara atfedilen adalet ve hareketlerde adalet (62).

Hobbes'a nazaran, «Adalete uygun ve adalete aykırı sözleri, bir șahsa izafe edildiği zaman bir mâna, hareketlere atfedildiğinde bir bașka mâna ifade eder. Bu sözler insanlara izafe edildiği zaman, davramıslarının akla uygunluğunu veya uygun bulunmadığını gösterir; fakat haceketlere atfedildiğinde, davranıșların veya hayat tarzmın değil, belli bazı hareketlerin akla uygun ołup olmadığını gösterir; belirtir. Bu sebepten dolayı âdil adam, bütün hareketlerinin. adalete,uygun olmasına çok dikkat eden adam, gayri âdil kimse ise, bunu ihmal edendir. Ve bizim dilimizde bu âdil ve gayri âdil kimseler, çok defa «haklı» veya «haksız» olarak geçerler... Adalete uygun hareket etmek bir fazilet, aykırı hareket ise günahtır.

Fakat hareketlerin adalete uygunluğu, o hareketierde bulunanın «âdil» veya «haklı» olarak tavsifini gerektirmez: yalnızca sự suz vasfını verir. Yine aynı șekilde, vaki olan adalete aykırılık, ki buna haksızilk denilir, bu harekette bulunanlara suclu denilmesine sebebiyet verir.»

g) Denkleștirici ve dağıtıcı adalet (63).

Hobbes ayrıca denkleştirici ve dağıtıcı olmak üzere iki nevi adaletten bahsetmektedir. Denkleștirici adalet-ki buna mübadelevì (= commutative) adalet de denilebilir-«âkidin mukavelede kendisine düșen mükellefiyeti ifa etmekle, bir șeyi satmakla, satın almakla, kira-

(61) Leviathan... Sf. : 96

(62) $\gg \quad \gg 7$

(63) Leviathan... Sf. : 98. Burada ««commutative Justice» yerine «denkleştirici adalet» demeyi daha uygun bulduk; mamafih, «mübadeleví adalet» de denilebilir. 
lamakla, ariyet vermekle, değiștirmekle ve diğger mukavele nevileri ile, mukavelenin icabını yerine getirmesidir. Dağıtıcı veya paylaștırıc1 adalet ise, hâkimin adaletidir; neyin âdil olduğunu tayin fiilidir.» (64).

B-) Dördüncü tabiat kananu minnettarlik

Hobbes'a göre «nasıl adalet daha önceki bir mukaveleye tâbi ise, minnattarlık da daha evvelki bir lûtfa istinat eder; lûtuf, daha evvel vaki hibedir. Ve dördüncü tabiat kanunu șu șekilde ifade edilebilir: Bir bașkasından, yalnızca onun lûtufkârlığ̣ sebebiyle bir menfaat temin etmiş olan kimse, bu lûtufda bulunanın, makul bir sebeb olmadan, kendi iyi niyetliliğinden pişman olmaması için, elinden gelen gayreti göstermelidir». Hobbes burada, bir kimsenin ancalk kendi menfaati mülâhazası ile hibede bulunacağını, hibenin mzaî akitlerden olduğunu, menfaattar olanın bir mükellefiyeti olmamakla beraber, bağıșliyanın iyi niyetini haklı çlkaracak surette hareket etmesi gerektiğini, aksi takdirde hiç kimsenin bașkasının yararına hareket etmek lüzumunu hissetmiyeceğini bunun da neticede harp halinin devamına müncer olacağmı söylüyor.

C-) Tabiatkanunlarıdanbeşincisi: ka rṣll k11 müsamaha veya hos görürlük (65).

Hobbes'a nazaran, «Tabiat kanunlarından beșincisi, herkesin diğerlerine karșı müsamahakâr hareket etmeye çalıșmasıdır». Hobhes müsamahakâr hareket etmekten tahammülkâr olmayı anlamaktadır. Ona göre bu tahammülkârlık bir nevi mecburiyettir: Bir kısım insanların, diğerlerine nazaran farklılık gösteren özelliklerine, eğer bunların düzeltilmesine imkân yoksa, tahammül etmek gerekir; bu sulhü korumanın bir icabıdır. Müsamahakâr hareket etmek, yani tahamül etmek bir kanundur; sulhü konumanın ve SOCTABLE olmanın bașka yolu yoktur.

\section{D-) Altincisi.: Affedilme firsativerme (66).}

«Istikbale muz'af bir tedbir» olarak bir kimsenị geçmişte ișlediği ve pișman olduğu suçları affedilmelidir; bu affedilme Hobbes'a göre, sulh için bir lûtuftan bașka bir șey değildir.

(64) Leviathan... Sf. 99.

(65) Leviathan... Sf. : 99

(66) Leviathan... $\gg: 99-100$.

A. Huk. F. Der. 
E-) Yedinci tabiî kanun : Intikamlar ve insanlarin yalnizca istikbale bağlanmalari (6

Hobbes bu konuda șunları söylüyor: «Intikam almak, fenallk için fenallk yapmak suretiyle cezalandırmaktadır. Insanlar, mazideizi kötülüklerin büyüklüğüne bakmamall, istikbaldeki iyikliklerin büyüklüğüne bağlanmalıdırlar». Bu kanun, bir evvelki affa dair ol:גnın bir neticesidir; Hobbes'a göre, intikam almakla iș bitmez; her son bir yeninin bașlangıcıdır. Zaferin sonu yoktur; zafer boșunadır ve böyl? olduğu için de akla aykırıdır.

F-) Sekizinci tabî́ kanun Hakarete sebebiyetvermemek: (68).

Hobbes'a nazaran, «Hakarete meydan vermemek icap eder: çünkü bütün kin vè hürmetsizlik belirtileri, harbi davet eder... Hic kimse, sözle, haraketle veya jestlerle bașkasına hürmetsizlikte bulunmamalidir».

\section{G-) Dokuzuncusu: Gururakarsıgelmek}

Hobbes bu konuda oldukca uzun durmakta (69) ve hücumlarm bilhassa Aristo felsefesine tevcih etmektedir. Hobbes'a göre, saf tabiat halinde hangi insanın daha mükemmel olduğu yolunda bir sualin yeri yoktur; çünü evvelce de belirtildiği üzere, tabiat halinde insanlar birbirlerine eșittirler; eșit insanlar arasında mükemmeliyet farkı olmaz. Eșitsizlik, cemiyet kanunları ile birlikte ortaya çımıștır. «Aristo, POLITICA'nın birinci kitabında, kendi felsefesine bir temel teşkil etmek üzere, insanları, emretmeye lâyık olanlar ve emredilenler durumunda kalacaklar șeklinde ayırmakta, bununda tabiatları icabı olduğunu söylemektedir; bunu biliyorum.» diyor Hobbes. Müellifimize nazaran, bu yalnız akla değil tecrübeye de aykırıdır.«Kon. ai kendilerini idare etmeyip de basskaları tarafindan idare edilen budalalar pek azdır». Ayrıca, tabiat insanları müsavi yaratmıșa buna șïkretmelidir; çünkü böyle olmakla insanlar, müsavi sartlarla sulh hükümlerini meydana getirmeye yanașmıșlardır. Aksi halde sulh temin edilemiyecekti.

Hobbes nihayet, dokuzuncu tabiî kanununu șu șekilde ifade ediyorum diyor: «Herkes, tabiaten bir bașkası kendisine eșit olduğu için müteșekkirđir»; bu kaidenin ihlâli ise gurur, kibirdir.






\section{H一) Onuncusu : Büyüklük taslamamak:(70)}

Hobbes diyorki, «Bu kanun, bir bașka kaideye istinat eder: Ta biat halinden sulh ve sükûnun hâkim olduğu cemiyet haline geçer ken, hiç kimse kendisi için, başkasının kendisine ayırmasına razı ol madığı bir hakkı mahfuz tutmayı isteyemez. Çünkü bütün insanlar sulhü temin etmek mecburiyetinde olduklarından, haiz bulundukları hakların bazlarından vazgeçmek zorundadırlar. Ama bir takım baș ka haklar vardır ki bunlarm alı konulması icap eder; bunlarsız in san, hayatını idame ettiremez. Bu haklar, hareket etmek, su içmek hava almak, bir yerden bir bașka yere gitmek gibi haklardır». Hobbes'a göre bunlar olmazsa insan ya yașayamaz veya iyi yașayamaz. «Iște», diyor Hobbes, «bu safhada, yani sulhün temini sirasinda, insanlar, bașkalarına bahședilmesine müsaade etmeyecekleri hakları kendileri için talep ederlerse, bu, evvelki kanuna, yani tabiaten bir başkası kendisine eşit olduğu için müteşekkir olma kaidesine aykurı olur ve böyle olduğu için de tabî̂ kanuna aykırıdur». Bu kanuna yani, bașkalarma verilmesine müsaade etmeyeceği hakları kendisi için de istememe kaidesine uyanlara «modest» (=mütevazı), aykurı hareket edenlere ișe büyüklük taslayan kimse, «arrogant man» denilir.

Burada, bir noktaya temas etmek lüzumunu hissediyoruz. Umumiyetle Hobbes'un, tabiat halinden cemiyet haline geçişte insanlarin haiz bulundukları bütün hürriyetlerden feragat ettiklerini ileri sürdüğü ifade edilir. (Bakınız: Illhan Arsel, «Anayasa Hukukunun umumî Esasları» 'Ankara, 1955 Sf. : 146, Ayrica Recai G. Okandan, «Umumi Amme Hukuku Dersleri», İstanbul, 1952, Sf. 105-106), Bu yolda bir iddia yukarıda pek açık bir șekilde belirtildiği üzere, yerinde olmamak gerekir. Insanlar cemiyet haline geçerlerken bütün haklarından vazgeçmiş değildirler; yaşamaları için lüzumlu bir takım hakları alı koymuşlardır. Aksini iddia hem, Levi athan'ın metnine aykırı hem de Hobbes'a söylemediği bir fikri izafe etmek olur. Aslında, insan hayatı, emniyet ve sulhü sükûna büyük bir ehemmiyet atfeden müelliften, ferdin, yaşaması için lüzumlu haklarından dahi feragat ettiğini ileri süren bir görüș beklemek de kabil değildir. Fikrimizce mesele hürriyetin anlașllș çeșitlerindeki uyușmazlıktan zuhur etmektedir. Hobbes'a göre, ferdin kayıtsız șartsız hükümran lehine feragat ettiği hakkı siyasî mahiyette olanı kavramın bugünkü anlașılış șekliyle ifade edilmek gerekirse siyasî hürriyetidir; siyasî hürriyet ise, hiçbir zaman hürriyetin tamanı demek değildir.

(70) Leviathan... Sf. : 101. 


\section{1-) Onbirincisi : Nasafet : (71).}

Müellife nazaran, insan ile insan arasında vaki bir ihtilâfm hallin. de hâkimlik etmek üzere kendisine itimat edilen bir kimse, hakkı eșit olarak paylaștıracaktır. Hobbes'a göre bu dahi tabiat kanununun bir kaidesidir. Bu olmaksızın, insanlar arasınđaki ihtilâflar, harbe bașvurulmaksızın halledilemez. Yine Hobbes'a göre, hükmünde taraflı hareket eden, keyfî hüküm veren, nihayet tabiat kanununa karș: gelen hâkimin fiili harp sebebidir.

Iște herkese hakkı eșit surette dağıtma, ki bu aklen bir kimseye kendisine düșeni, kendisine ait olanı verme demektir, kanununa uygun hareket etmek, nasafet (=EQUTTY) olarak adlandirulir ve Hobbes'a göre evvelce belirtilen dağıtıcı adalet (=distributive justice) budur.

\section{I-) Onikinci : Umuma ait şeylerin oșitlik} üzere kullanll masi (72)

Hobbes'a göre bazı șeyler vardır ki bunlar bölünemezler; fakat eğer mümkünse umumun istifadesine arzedilebilirler. Ve eğer șeyin miktarı bir kayda tâbi olmalzsızın müsait ise, șey, üzerinde hak sahibi bulunanların sayısiyle mütenasip bir șekilde onların istifadelerine bırakılabilir. Bașka bir surette paylaștırma eșit değildir ve nasafete de aykirıdir.

\section{$\mathbf{K} \mathbf{u} \mathbf{r} \mathbf{r} \mathbf{a}$}

$$
\text { K-) Tabiat Kanunlarınan oniẹunciisü: }
$$

Müellife göre bazı șeyler vardır ki bunların hem bölünmeleri mümkün değildir hem de umumun istifadesine arzedilmelerine imkàı: yoktur. Equity'de (nasafet) ifadesini bulan tabiat kanunu, böyle şeyler üzerindeki hakkın tamamının o șeye ilk sahip olana verilmesini, ilk sahip bilinemiyorsa bunun kurra ile tayinini icabettirir: bașkaca bir paylaștırma sureti düșünülemez.

L-) On dördüucü tabiat kanunn:Ekber evlâdın. hakki ve ilk zilyed.

Hobbes'a göre, «Kurralar iki nevi oiur: Keyfi ve tabiî. Keyfî̀ kurra, rakipler arasında birisine bir şeyin aidiyyetinin tanınmasıdır. Tabî̂ kurra ise, ya ekber evlâdın hakkı veya ilk zilyed olmadır.

(71) Leviathan... sf. : 101.

$$
\text { - ... Sf, : } 101 .
$$


Demekki böylece ne umumun istifadesine arzedilebilen ve ne de bölünebilen, şeyler, ilk maliklerine veya zilyedlerine aid addolunmak, bazı hallerde ise önce doğana yani ekber evlâda bu șeyin mülkiyetini tanımak icap eder» (73).

Hobbes'un on bes ve on altınci tabiat kanunları olarak saydlğı, «sulhün kurulmasına tavassut eden bütün insanlar onun emin bir şekilde idare edilmesine izinlidirler» ile «yekdiğeri ile ihtilâfa düșenler, haklarınin bir hakem tarafından tesbit edilip hüküm altına alınması için ihtilâfı ona arzederler» üzerinde uzun boylu durmuyoruz.

\section{M-) On yedincisi : Higkimse kendi işinde hâ- kim ol a maz.}

Hobbes diyor ki, «Herkesin kendi menfaatı üzre hareket edeceği tahmin olunur; bu sebebten hiç kimse kendi dâvası için münasip bir hakem değildir. O kadar değildir ki, nasafet taraflardan her birine eșit menfaatler verilmesini gerektirse ve bir tarafın da hâkim olması kabul edilse, diğer taraf da kendisinin hâkim olarak kabul edilmesini ileri süreceğinden ihtilâf çlkacaktır; iște bu harp sebebidir ve tabiat kanununa aykırıdır» (74).

N-) On sekizinci tabiat kanunu : Taraflardan birini tutmakta menfaati olan kimsede hâki m ola maz

Müellif, hüküm verecek olanın tarafsızlığında israr etmektedir. Taraflardan birinin kazanmasını, șan, șeref vs. yüzünden istediği bir ihtilâfta bir kimse hakem olamaz; bu bilhassa rüșvet halinde varittir. Rüşvet almaktan kaçınmasına imkân olmasa bile, eğer bir kimse rüşvet almış ise, artık hiç kimse ona itimat etmek mecburiyetinde değildir. Hobbes'a göre taraflardan birini tutmakta menfaatı olan bir kimsenin hakemlik etmesi hali harp sebebidir ve bu hal tabiat kanununa aykirıdır. (75).

\section{O-) Ondokuzuncusu : Deliller hakkinda.}

Hobbes burada daha ziyade delillerin kudretinden bahsetmektedir: Herhangi bir vakıa ihtilâfında hâkim, karara varmak için yalnız bir delille, yetinebilir; bir başkasında yetinmeyebilir. Iki, üç dört hatta daha fazla delilin mevcudiyeti gerekebilir: Meğerki mesele hakkında bir kanaate varılabilsin..

(73) Leviathan... Sf. : 102.

(74) Leviathan... Sf. : 102

(75)

$\gg \quad \ldots$ : 102 
Hobbes, «Sulhü emreden tabiat kanunlarının bunlardan ibaret.» bulunduğunu söylüyor (76); fakat müellif bu kaidelerin hepsinin akılda tutulmasınm ve tatbikinin zorluğunu kabul ediyor ve bunlarin hepsinin tatbikinde kolaylaștırıcı bir vasita olarak bir umumi kaide kabulü teklifinde bulunuyor; bu, «Sana yapılmasını istemediğin șeyi bașkasina yapma» dır.

7. - DEVLETtN, Hobbes a göre devlet, «Insanların, sulh ve müșHƯKUMRANIN ierek müdafaayı sağlamak için, karșıllkh bir mukàve TEB'ANIY vele ile bütür tasarruflarında, umumun iradesini kenTARIFI disi nasil münasip görürse o șekilde kullanmak selâhiyetine sahip kıldıkları, bütün cemaat namina hareket eden bir șahistur» (77). Görülüyor ki Hobbes'a göre devlet, umumun iradesini șahsinda temsil etmektedir; bu mânada bir devletin teșekkülii ise yine mukavele ile olmaktadir: «Kendimi idare etmek için malik olduğum hakkı, bu șahsa veya meclise, bașkalarının da aynı mahiyetteki haklarını aynı meclise veya şahsa, burakmaları șartiyle, devrediyorum» (78). Böylece Devlet teșekkül eder ve buna COMMENWEALTH denilir; Lâtincesi CIVITAS'dır.

Devlet, fani Allah (=Mortal God) dir.

Isste bu devleti, devlet denilen müesseseyi idare eden șahsa hühükümran, ve bu șahıs hükümranlik kudretine sahiptir, denilir; geri kalan herkes onun teb'asidrr.

Hobbes burada önemli bir noktaya dokunmakta ve hükümranik kudretinin ixi șekilde kazanlabileceğini ifade etmektedir. Bu yollardan birincisi tabin kudret (=natural force) ile hükümranlık kudretinin kazanılmasıdır: Nasıl bir baba çocukları üzerinde otoritesini tesis ediyor onlar da babalarina tam mânasiyle itaat ediyorlerș. aynı vetire toplum için de varittir. Bir kimse yalnız tabin̂ kuvveti sayesinde diğerlerinin itaatinin sağlayıp hükümran kudrete sahip duruma geçebilir. Diğer yol, müiellifimizin ifadesine göre, insanların rzaî olarak, bir kișiye itaat etmek arzusu ile kendi aralarında bir anlaşma yapmalarıdır; buna karşllik, itaat edecekleri kimse onları her tehlikeye karșı koruyacaktır. Hobbes'a göre, bu ikinci șekilde

(76) Leviathan... Sf. : 103.

(77) $\gg$ : Sf. : 112; ayrica bakını: AKBAY; «Umumî Amme Hukuku Dersleri» 3. Baskı, Ankara, 1958 Sf. : 27' den naklen HOBBES, «De Cive» L' Empire, V, IX.

(78) Leviathan... Sf. 122; ayruca, AKBAY, a.g.e., Sf.: 27. 
kurulan devlete siyasî COMMENWEALTH denilir. Diğegri ise müktesep devlet seklidir.

8 - MÜESSE-

SEVI BIR ŞE-

KILDE DEVLE-

TIN KURULU-

SUNDAN GT- ğdadır (179):

LER.

\section{A一) Teb'a, devletin şeklini de ğiştiremez.}

Cünkü teb'anın ilk mukavele hükümlerine riayeti asıldır. Mukavele ile devleti kurmuşlar ve neticede bir tek şahsin hükümlerine uymayı, tasarruflarını tanımayı kabul etmișlerdir; kendi aralarında meșrû bir șekilde yeni bir mukavele yapamazlar; yapamaynca devlet șekilini de değiştiremezler. (80)

\section{B-) Hüküman kudret cezalandrrlamaz (81).} dir:

Çünkü hükümran tarafından mukavelenin ihlâli mümkün değil-

Mukavele, teb'a arasında aktedilmiștir. Hükümran taraf değildir. Taraf olmadığı bir mukaveleyi hükümranın ihlâli düșünülemez; böyle olduğu için de cezalandırılamaz.

C-) Hickimse çŏgunluk tarafindan ilân edilen hükümran kudreti protesto edemez

Hobbes bunu şöyle izah ediyor: Çoğunluk, rızasını açığa vurmaks suretiyle bir hükümran ilân edince, buna muhalif olan da șimdi. rızasını ızhar etmek zorundadır; bu, onun, yapacağı bütün hareketlerin kendisine bildirilmesine veya, aksi takdirde sadece çoğunluk tarafından yokedilmesine razı olması demektir. Buna mukabil eğer fert kendiliğinden, kendi rızası ile cemaata dahil olmuşsa, bu zımnen mukaveleyi kabul ettiğini gösterirki bu da, çoğunluğun emrine itaat etmeyi gerektirir ve bu sebeten, çoğunluğun emrini yerine getirmemeye veya ona karşı direnmeye kalkıșırsa, mukaveleye aykırı hareket etmiş olur. Netice itibariyle fert, cemaata dahil olsun olmasın kendisinden rızasını izharı istenilmiș bulunsun bulunmasin, her halükârda onun çoğunluğun kararlarına itaat mecburiyeti vardır (82)

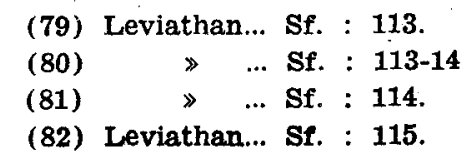




\section{D-) Hükümranın hareketleri, teb'a tarafin- dan ithamedilemez.}

Hobbes'a göre bunun sebebinin izahı oldukça gariptir: Hükünırandan, teb'asına bir fenalık gelmesi beklenemez; buna imkân da yoktur; böyle olunca, onlar da hükümranı adaletsizlik ve haksızlıkla itham edemezler (83).

E-) Hükümran, herhangi bir fillindendolay cezal a nd r 11 a maz.

$\mathrm{Bu}, \ll \mathrm{D} »$ de izah edilen hususun mantıkî bir neticesidir. Buna mukabil hükümran, kendi fiillerinden dolayı bașkasun cezalandırır.

F-) Hükümran, kenditeb'ası icin noyin sulh içinde yaşamalarina ve müdafaularina yararls oldağun bizzat tayin ve tosbit oder.

Burada Hobbes, hürriyetler nizamı bakımmdan son derece önemli basım ve öğretimle ilgili fikirler ileri sürmektedir. Gerçekten müellife göre, teb'anın müdafaasıı ve sulh içinde yașaması için neyin ya. rarlı olỏuğunu tayin ve tosbit etmek hakkı hükümrana ait olunca, bunun bir neticesi olarak, haükümranın, kaçınıması, men'edilmesi caiz doktrinleri, fikirleri tesbit ve tayin eylemek haklkı ortaya çıkar. Netekim hükümran, bazı dolktrinleri ve fikirleri, teb'asmun sulh içinde yașaması ve müdafaası için uygun görmediğinden men'etmiștir. Hobbes bu noktada, bütün doktrin kitaplarınin basımlarından evvel inceleneceğini kabul etmektedir (... examine the doctrines of all books before they be published...) (84) ; aynı görüșün bir neticesi olarak, memlekette yalnız hükümranın tecviz ettiği doktrinlerin öğretimi yapulacaktır.

G-) Kaideler vazetmek hakkinda doğrudan doğruya hükümrana aittir vehigkimsebu hakkl ondan al amaz.

Hobbes, "Yedinci olarak, kaide vaz'etmek hususundaki kudretin tamamı hükümrana aittir ve bu suretle herkes, kendileri gibi tebadan olan bir bașkası tarafından rahatsız edilmeksizin ne gibi șeylerden faydalanabileceğini, hangi hareketleri yapabileceğini bilebilir» diyor (85) ; Hobbes'a göre bu, insanların âdap-erkân (= propriety)

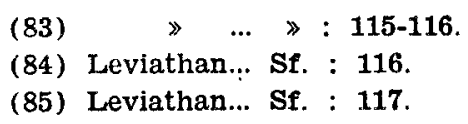


dedikleri șeydir. Daha önce de belirtildiği üzere, hükümran kudretin teessüsünden evvel, propriety de yoktu; zaten, sulhü temin için hükümran kudretin tesisi gerekmiş o da propriety'yi yâni, âdap ve erkân kaidelerini vaz'etmiștir.

H-) Kaza hakki veihỉâfları karàra băğlama selâhiyeti de hükümrana aittir.

Hobbes'a göre hükümran, muttali olduğu hukukî ihtilâfları bir karara bağlamak selâhiyetini haizdir; bu ihtilâflar da medeni hukuktan, veya tabiî hukuktan yahut sadece vakialardan doğmuș olabilir. Thtilâf haline düșüldüğünde bunun halledilip karara bağlanması imkânı bulunmasaydı, ferdi bir bașkasının zararlı fiilinden masun kı lacak hiç bir koruyucu tedbir mevcut olmayacaktı; bu, azgın arzularin hâkimiyetini ve tabiat haline dönüșü tazammun eder; devietin teessüsünde güdülen gayeye de aykırıdır (86).

I-) Harbetmek ve sulh yapmak hakkı da hüküm rana aittir.

Hobbes diyorki, «Dokuzuncu olarak, başka milletler veya devletlerle harbetmek veya onlarla sulh yapmak hakkı da hükümrana aittir; bu onun, umumun iyiliğinị tâyin ve tesbit edebilmesinin bir neticesidir ve yine 0 , ne miktarda kuvvet toplanacağını, bunların nasll silâhlanacağını, kendilerine ne ödeneceğini tâyin eder» (87).

I-) Memurları tâyin etmek hakkı hükümrana aitir.

Hobbes'a göre «Onuncu olarak, gerek harpte ve gerekse sulhta, bütün konsilleri, bakanları, majistraları ve diğer memurları seçmek hakkı hükümrana aittir» (88); burada seçmekten ziyade bir tâyin bahis konusudur.

K-) önceden bir kanunla tesbit edilmediği takdirde Hükümran, ceza ve mükâfatin ölçü sün ü keyfî olarak tâyin eder.

Hobbes burada genel kaideyi su șekilde vaz'etmektedir : Fertler, ceza ve mükâfatlarm ölçülerini tesbit eden bir kanuna göre, hükümran tarafından mükâfatlandımlırlar ve cezalandırılırlar; fa-

(86) Leviathan... Sf. : 117

(87) Leviathan... Sf. : 117-118.

(88)

$\gg \quad \cdots: 118$. 
kat ölçüleri bildirir bir kanun mevcut olmayabilir; bu takdirde hükümran ceza ve mükâfatın ölçüsünü tesbit eder (89).

L-) Nihayet, şeref payesi ve nişan vermek hakki da hük ümrana attir.

Hobbes'a göre, harpte diğerlerinden daha fazla yararlık gösteren, kralı (hükümranin emirlerine tamamen riayetkâr ve nihayet, baskalarından farklı kabiliyet ve meziyetleri olan kimseler bulunabilir; bunların bu kabil özelliklerini nazara almak gerektir; yani kendilerine nișan verilir; șeref payesi tevcih edilir.

9. - HUKUUMRA- Hobbes, hüküimranın haklarının bölünemiyeceğini isNIN HAKLARI rarla belirtmektedir : Aslinda bu haklar, ayrilmaz. BOLTNEMEZ. bölünmez ve beyan da edilmez. Bununla beraber, hükümranın bütün haklarının bölünemiyeceğini, daha doğrusu bir kısım haklarının kullanılmasını bașkalarına bırakmıyacağını zannetmemelidir. Para basmak ve buna benzer bir kısım haklar vardırki. hükümran bunları bașkaları vasitasiyle kullansa, veya kullanılmaların bașkalarina bıraksa da olur; fakat herhalde teb'ayı korumağa ve savunmaya matuf hakkını hükümran bir bașkasina intikal ettiremez. Hobbes'a göre, hakların ayrılması veya bölünmesi, Devletin ortadan kalkmasina sebebiyet verir.

«Kendi içinde bölünmüș bir devlet, ayakta duramaz» (= A kingdom divided in itself can not stand). Eğer Ingiltere'de iktidar, Lordlar ve Avam kamaraları ile kral arasında bölüșülmemiș olsa ve eskisi gibi kral tek bașına iktidarın sahibi bulunsa idi, Ingilizler iç harbin felâketlerine uğramayacaklardı. Hobbes için özlenen durum, bu otorite çokluğuna ve ayrliğına son verilip, kudretin tek elde toplanmasının sağlanmasıdır (90).

10. - DEVLET Leviathan'ın XTX. «Chapter» ini Hobbes, çeșitli DevŞEKILLERt let șekillerine ve hükümranlık kudretinin ele geçiriliș yollarina tahsis etmiștir.

Hobbes'a göre üç çeșit devlet tipi vardır : Monarși, demokrasi ve oligarși. Birbirine benzeneyen devletlerin mevcudiyeti, suveren'lerinin farklılığındandır. Asıl, ceșitli devlet șekilleri değil, birbirinden farkh hükümranlar vardır. Suveren yani hükümran, bir sahıs veya meclis olur. İktidar meclisin olduğunda iki hal düşünülür : Ya bu üstün iradenin kullamilmasına meclise dahil olan herkes iști-

(89) Leviathan... Sf. : 118.

(90) IJeviathan... Sf. : 118. 
rak eder; veya etmez; yalnız meclis üyelerinden bir seçkinler grubu bu üstün iradeyi yani iktidarı kullanir. Görülüyor ki, üç tip devlet şekli ortaya çlkmaktadrr : Suverenite'nin yani hükümranlığın temsilciliği bir șahsa mevdu ise, o takdirde devlet bir monarşidir. Ùstün irade bir mecliste tezahür ediyor ve bunun kullanılmasina meclise dahil olan herkes katilyorsa, bu demokrasi veya halk devleti (= popular commonwealth) dir. Hobbes'a göre demokrasilerdeki halk meclisinin terekküp tarzı da ikiye ayrilır : Ya halktan olan herkes, meclise dahildir; girebilir - ki burada müellif bütün bir halkı kapsayan muazzam bir meclis düșünüysr olmalıdır - ; veya bir kısım halk, ama kalan kitleyi temsil eden ve onlardan tefrik edilmiş kimseler meclisi teșkil eder. Meclis bir kısma veya gruba has veya mahsur ise, o zaman buna aristokrasi denilir.

Müellifin fikrince, bu üç neviden bașka devlet tipi olmaz; fakat tarihte bașka adları tașıyan devlet şekillerine de rastlanılmıștır : Tyranny ve oligarchy gibi. Hobbes'a göre tirani ve oligarși, monarși ve aristokrasinin diğer isimlerinden bașka bir șey değildir. Monarșiden hoșnut olmayanlar ona tirani demișlerdir. Oligarși ișe, aristokrasiyi sevmeyenlerin ona verdikleri addir. Bununla beraber, Hobbes'a nazaran, demokrasiye de, bu rejimde ıstırap çektikleri için anarsi diyenler de vardır.

Ikinci derecedeki iktidar mihraklarmnn mevcudiyeti tehlikelidir. Müëlife göre yalnız bir tek ve en üstün iktidar mihrakı bulunmalıdır. Diğer iktidar mihrakları bulunmamalı ve mevcudiyetlerine imkân verilmemelidir. Ayrı iktidar mikrakı bir muhalefet merkezi demektir. Tkinci derecedeki iktidar mikraklarnm mevcudiyeti neticeten, üstün kudretin bölünmemesi yolundaki ana prensibe aykırıdır. Hobbes, bu noktadain hareketle devlet șekillerinin mukayesesini yaparken, monarșiyi tercih etmesinin sebeplerini açılamaktadır (91). Gerçekten müellifimize göre, bu üç çeșit devlet tipi arasındaki ayrılık, yalnızca iktidarı elinde tutan mihrakın tekliğinde veya çokluğunda mündemiç değildir : Sulhün temini ve emniyetin devamını sağlamak bakımmdan devlet tiplerinin elverișlilikleri, birbirinden ayrıdır. Önce bir monarși nazara alınacak olursa, monarkın, bir meclisin, o meclisi teșkil eden üyelerin fikirleri ile bağlı olmaksızın kendi iradesine göre hareket edebileceği hakikati ortaya çıkar. Bu yüzden monark, umumun menfaatine harekette daha dikkatlidir. Hobbes burada çok dikkate değer bir fikir ileri sürmektedir : «Monark da

(91) Leviathan... Sf. : 122. 
kendi ailesinin, yakınlarının, arkadașlarının menfaatleri yararına. hareket eder; bunu kabul ediyorum» diyor. Yalnız șu var ki, monarșide monarkın menfaati, umumun menfaatindne ayrı, ondan farklı değildir ( = Now in monarchy, the private interest is the same with the public) (92). Monarkın zenginliği, kudreti ve șerefi, teb'asının zenginliği, kudret ve șerefinden kaynak alır. Teb'ası fakir, güvensizlik içinde bulunan monark da zengin ve huzur içinde değildir.

Demokrasi ve aristokrasilerde ise, müellife göre, halkın saadeti ile idare edenlerin menfaatleri arasinda böyle bir ayniyyet mevcut değildir; bilâkis, hükümran bir meclis olduğu zaman, meclis umumun menfaatinin tahakkukunda, bir tek șahıs yeni monark kadar dikkatli değildir.

İkinci olarak monarșide, monark istediği zaman memurlarının fikirlerini alır; sonunda kendi iradesi neyi muvafik buluyorsa onu yapar. Halbuki bir meclisin hükümranllğı halinde durum tamamen farklıdır : Herkes kendi doğıu bildiğini, ekseriya menfaatine uygun olanı söyler ve onun tatbik edilmesini ister. Menfaatler ve ihtiraslar çarpıșır. Hangi hareket hattının tercih edilmesi gerektiğinin ise. ekseriya farkına varilmaz.

Hobbes'a nazaran üçüncü olarak, bir monarkın bir hususu düșünmesi, teemmülü, kararsızlığa dûçar değildir; o insan tabiatinin icabı olarak düșünür ve messeleleri karara bağlar: fakat bir mecliste meselelerin düşünülüp karara bağlanmasında, insan tabiatını bir tarafa bırakalım, asıl, meclis üyelerinin sayısını artması nisbetinde fazlalașan bir kararsızlık rol oynar. Meclisin düșünmesinde kesinlik yoktur.

Dördüncü olarak bir monark, kendi kendisiyle ihtilâfa düșmez: bir meclis ise düșebilir ve bu da bir iç harbe yolaçabilir.

Beșinci olarak ise, Hobbes, önce monarșinin aleyhine bir noktayı belirtmektedir. Müellife göre, monarșinin de uygunsuz, tasvip edilemiyecek bir tarafı vardır : Monarșilerde bir șahıs, yani teb'adan herhangi bir kimse, türlü sebeplerle kudret sahibi olur ve zenginleșirse, geriye kalan herkesi kendi sahip olduklarından mahrum edebilir. Hobbes, «İtiraf ederim, bu büyük bir uygunsuzluktur» diyer; fakat ayn șey, daha büyük ölçüde olmak üzere, demokrasi ve aristokraside de varittir.

(92) 123. 
Altıncı fakat yine monarșinin aleyhine olarak Hobbes'un ileri sürdüğï husus, monarşilerde monarkın vefatı ile hükümranlı̆̆ın bir küçüğe intikali halinde, karșılașlan güçlüktür. Müellife göre bu küçük tahta ehil ve iyi, ehliyetsiz ve fena olabilir; daha doğrusu, iyi ile kötü arasında farkı anlamayacak durumdadır. Bu takdirde, iktidarı onun adına bir bașka şahıs veya bir meclis kullanmalıdır. İște uygunsuzluk, Hobbesa göre buradan doğmaktadır : Iktidarın bir bașka șahsa veya bir meclise tevdii, bütün devletler için, iç harp ve karıșiklıktan da daha fena kir uygunsuzluktur. Hobbes bu uygunsuzluğu ortadan kaldırmak için, yerine küçük bir monark bırakacak hükümranın vefatından sonra bu küçüğuin, tâbir caizse hükümranlık öğreticisinin, vasiyetname ile sarahaten veya zımnen bildirilmesinin yeteceğini belirtmektedir. Bundan sonra, teb'a eğer kendi vazifelerinin neler olduğunu ve hükümranın haklarmın nelerden ibaret bulunduğunu biliyorsa, mesele yoktur. Eğer hâlâ çocuk kralın idaresi altındaki monarşide, umumî sulhü bozacak hareketler vuku buluyorsa, bu artık monarșik devlet șekline değil, fakat ancak teb'anın ihtiraslarına bağlılığına ve kendi vazifelerini bilmekteki cehaletine atfedilebilir.

11. - KARIşזK Hobbes, üçe ayırdığı devlet şekillerinden başka, bir DEVLET ŞEKIL- takım özel devlet şekillerinin mevcudiyetine dikkati LERI çekmektedir. Gerçekten müellife göre, yer yüzünde öyle devlet şekilleri vardırki, bunları üç ana gruptan herhangi birisine sokmak kolay değildir ve hattâ bu yüzden bunların ayrı birer nevi olarak kabul edilebilmeleri mümkündür (93). Meselâ seçimle taayyün eden (müntehap) krallıklarda, kral iktidara hudutlu bir süre için sahiptir; bununla beraber bu kabil devletler, bir çok müellifler tarafından monarşik tipte sayılmaktadır. Aynı șekilde bir demokratik veya aristokratik devlet tipi, zorla bir düşman devlete inkiyat eder ve onun tarafından idare edilmeye bașlanılırsa, belki ilk bakıșta bu devletlerin hâlâ demokratik veya aristokratik bir iđare şekline tâbi bulundukları zannedilebilir; fakat öyle değildir. Nasıl seçimle gelmiş kraller suveren sayılamaz, ąncak suveren'in nazırlari (= ministers of severeign) olarak kabul edilebilirlerse, aynı șekilde böyle zorla bir başka devletin otoritesine boyun eğmiş devletler de, demokratik veya aristokratik bir idare şekline bağlı görünseler bile, aslında tamamen monarșik bir șekilde idare edilmektedirler.

(93) Leviathan... Sf. : 125. 
Hobbes burada, ilgi çekici bașka bir noktaya dokunuyor (94); Seçimle gelen bir kralın iktidara sahip bulunması, hayat süresi ile hudutlandırılmıs olabilir; yahut, Roma diktatörlerinde olduğu gibi, sene veya aylarla sinırlandırlmıștır; fakat bu seçimle gelen krala, kendisinden sonra iktidar mevkiine gelecek olanı tâyin etmek hakkı tanınmıș ise, kendisinden sonra gelen kralın durumu ayrilık gösterir. Müellife göre, seçimle gelmiș kralın kendisinden sonrakini tâyin etmek hakkına istinaden krallık mevkiine gelmiş olanın artık «seçilmiș olmak» sifatından bahsedilemez; 0 , tahta tevarüs suretiyle kral olmuș sayılır. Hükümrana kendisinden sonrakini tâyin etmek hakkının tanınması yerindedir; eğer ona böyle bir seçim hakkı tanınmamıș bulunsa idi, ölümünden sonra bir meclis veya bir bașka şahıs, onun yerine geçecek olanı seçmek mecburiyetinde kalacaktı: veya devlet parçalanacak, telkrar harp başlayacak, tabiat haline dönülecekti.

Hobbes'a göre, kudreti sinırlandırılmıș bir kralın, onun kudretini sinırlayana veya sinırlayanlara karșı üstünlüğü düșünülemez; bu yolda bir üstünlüğün mevcut olmaması, kudreti smırlandırılmıs kralin, hükümran olmaması dernektir. Bu suretle hükümranlık kralda değil, daima kralın otoritesini veya kudretini sınırlandırmak hakkı. na sahip bulunan meclisde mündemiçtir. Netice itibariyle böyle bir devlet bir monarși değil, fakat ya bir demokrasi veya eski Isparta da olduğu gibi, (ki Isparta'da kralların orduları idare etmek imtiyazları vardı; fakat hülümranlık Ephori'de tașahhus etmiști! bir aristokrasidir.

Bütün bunlardan sonra müellif, devlet șekillerini bir kere daha ș șekilde tarif etmektedir : Her nerede halkın arasından bazılarının seçimleri suretiyle kurulrnuș bir meclis iktidare sahipse, orada demokrasi veya aristokrasi vardur; bununla beraber halk, kendisinin seçmediği bir meclis tarafından idare ediliyorsa, bu monarșidir: Yani burada bir kimsenin bütün halk üzerinde monarșik idaresi değil, bir halkın diğer bir halk üzerinde monarșik idaresi bahis konusudur (95).

Bütün bu devlet sekillerinde mesele, fani olmaktadır. Yalnız monarklar değil, bütün 'bir meclis dahi ölür. Halbuki, insanlarm sulh içinde yașamalarının devamı için, nizamın sun'i bir șekilde de olsa idamesinin sağlanması, âdeta sun'i bir ebediyetin temini șarttır. Ak-

(94) Leviathan... Sf. : 125-126.

(95) Leviathan... Sf. : 126. 
si halde insanlar her çağda, bir tek kiși veya bir meclis tarafından idare edilmekte bulunsunlar, bu meclisin veya sahsin fani hayatun tamamlaması neticesinde, tekrar harp haline döneceklerdir. İşte bu sun'i ebediyetin sağlanması çaresini insanlar, tevarüsle bulmuşlardir.

Tahta tevarüsün, mevcut suveren tarafindan tâyin ve tesbit edileceğini kabul eden devlet șeklinden daha iyisi, Hobbes'a göre, yoktur. Tahta varis tâyininin bir bașka șahsa veya hususî bir meclise verilmesi doğru değildir.

Hobbes bu tevarüs bahsinde, dikkate değer addettiğimiz șu fikri ileri sürmektedir : «Bir demokraside, idare eden meclisin üyelerinin tamamını fena bulması yani ölmesi düșünülemiyeceği için, tevarüs hakkından doğan meselenin bu hükûmet șeklinde bir yeri yoktur.» (96) ; bununla beraber, müellifin burada taraftar olarak göründüğü fikir, yukarıda meclislerinde insanlar gibi fena bulacaklarını kaydetmesi karșısında, bize çelişik görünmektedir.

Hobbes'a göre tevarüs hakkı bakımından asıl büyük güçlüğe monarșilerde rastlanır; bu meselenin kesin bir șekilde halledilmesi, mevcut monarka kendisinden sonra kimin hükümran olacağını tâyin ve tesbit etme hakkını tanımakla mümkündür.

12. - TEB'ANIN Hobbes, Leviathan'In XXI. kesiminde, teb'anın hürHƯRRTYETI riyetinden bahseder. Bu kesimde belirtilen fikirleri kısaca tesbite çalışalım.

A - Hüriyet nedir ? Hobbes'a göre hürriyet, bașlıca muhalefetin, yani hareketin haricî mânilerinin yokluğunu tazammün eder. Muhalefet, yani hareketin vukuuna meydan vermeyecek haricî mâniler mevcut olduğu surette, fert hür değildir; çünkü belli bir alan dahilinde hareket etmek kabiliyetinden mahrumdur (97).

B-) H ii olmak ne demektir? Hobbes'a göre, «Yukarida kaydedilen esasa (A-) ve umumiyetle kelimenin cari mânasına göre, hür olan, yapmak istediği șeylere mâni olunmayan, bunları kendi kuvvetiyle yapabilen kimse demektir»; demekki hür olmak bunları yapabilen kimse olmaktır.

C一) Korku ve hürriyet es anlamlidir. Hobbes, hürriyet ile korkunun aynı mânaya geldiğini kabul etmektedir; ona göre, «Meselâ bir kimse geminin batacağı korkusu ile mallarını

(96) Leviathan... Sf. : 127, (97), Leviathan. Sf. : 137-137. 
denize atmıșsa, șüphesiz bunu kendi isteği ile yapmıștır ve eğer isteseydi atmayabilirdi de... Hür olan bir kimsenin de hareketi bu mahiyettedir : Borçlu çok defa hapishane korkusu, yüzünden borcunu ifa eder; öyleki, borcunu ifa etmediği takdirde, onu hapishaneye düșmekten kurtaracak hiçbir kuvvet yoktur. İște borçlunun bu yoldaki hareketi, hür bir kimsenin hareketidir ve umumiyetle bir devlet içinde, halkın hareketlerinin tamamı hukuk korkusu yüzünden yapilmaktadir» (98).

D-) Hürriyet ve lüzum eş anlamilidir.

Müellife göre, insanların kendi rızaları ile yaptıkları hareketlor kendi iradelerinin, yani hürıiyetin icabını yapmaları demektir; fakat, insan iradesinin her hareketi ve her nevi arzusu, hatta meyli, bir sebebten neș'et etmektedir; bu sebeb de bașka bir sebebten doğar ve bu zincirin halkaları böylece devam eder; fakat ilk halka Aliah'a elindedir ki, o, bütün sebeblerin ilkidir. Böylece, insanların kendi iradelerine göre yani hür olarak hareket etmelerinde, kendilerine Allah'm iradesine de uygun hareket etmekten ibaret lüzum režakat etmektedir. Fakat Hobbes, insanların Allah'in emretmediği ban hare. ketleri yapabileceklerini kabul etmektedir; fakat bu üzerinde durulacak bașka bir meseledir. Varılan netice, hür olarak hareket etmenin bir lüzuma uygun hereket demek olduğudur.

E-) Teb'anın hürriyeti, kanunlarin mis a ade ettigri sahalarda kendi iradelerine uygun hareket etmelerinden ibarettir.

Hobbes'a göre, yeryüziinde, fertlerin bütün fiil ve sözlerini düzenleyecek yeterlikte kanunlar koymus hiçbir devlet yoktur; aslında bu mümkün de değildir. Kanunlar tarafmdan düzenlenen alanlarda ise, fert iradesinin serbestce tezahür ve tecellisi imkâm tanımmiștır. Meselâ ferdin almak, satmak veya bașka surette akitte bulunamak hürriyeti vardır. Fert, kendi evini seçer; yașayıș șeklini istediği gibi tayin eder ve kendi istediği ve uygun bulduğu șekilde çocuklarmı yetiștirir. Bu ve benzeri sahalarda ferde serbestî tanımması ancak hükümranmin müsaadesi ile olmuștur.

F-) Müelliflerin tervic ettikleri hususi sahıs ların hürriyeti de ğil, hükümranların hürriyetidir (99).

Hobbes, bu genel kaideyi vaz'ettikten sonra, Romali ve Yunanlılar da bunu kabul ederler, diyor. Fertlerin her istediklerini yapa-

(98) Leviathan.. Sf. : 137 
bilmeleri, müellife göre, hürriyet değildir ve her istediğini yapabilmek, sadece devlete mahsustur; ancak devlet her istediğini yapabilir Aslında, fertlerin her istediklerini yaptıkları veya yapabildikleri yer. de, devlet yoktur. Hobbes'a göre, «Romalılar ve Atinalılar hür idiler; çünkü devletleri hür idi.» Devlet șeklinin monarşik veya demokratik olmasınm, terviç edilecek hürriyetin devlete ait bulunması prensibine tesiri yoktur.

13. - POLITIK Hobbes, teșkilâta hasrettiği Leviathan'ın XXII. keve OŻEL KURU- siminde bunu, bir insan vücudunun kaslarina benLUŞLAR. zetmektedur.

«Teșkilâttan,-ki o buna sistem diyor-bir kısım insanların, bir işin görülmesinde veya belli bir hususta, menfaatte, birleșmelerini anliyorum» (100) diyor.

Hobbes'a nazaran kuruluşların bazıları nizami, bir kısmı ise gaym nizamî olur. Insanların tamamı namına iș görecek, onları temsilen bir meclis teșkil edildiğinde veya bu vazife bir șahsa verildiğinde, bir nizamî kuruluş meydana gelmiș olur. Geriye kalan bütün kuruluşlar gayri nizamîdir.

Nizamî kuruluşların bir kısmı mutlak ve bağımsızdırlar; bunlar; kendi temsilcilerinden gayri kimseye tâbi değildirler; bu kabil kurulușları 'yalnız devletler teşkil eder.

Tkinci kısım, yani gayri nizamî kurulușların bir kısmı özel, bazıları ise politik mahiyettedir. Politik mahiyette olanlara, siyasì müesșeseler denilir; bunlar, hukukî șahıslar olarak da adlandırılabilir. Siyasî müessese veya kuruluşlar, otoritelerini devletin hükümran kud retinden almaktadurlar; ama bu, hükümran kudretin kendi otoritesinden onlara bir miktar verdiği mânasına gelmez. Özel kuruluşlardan ise, fertlerin bir araya gelerek, veya bir yabancının otoritesi ile tesis ettikleri kuruluș anlașlır.

Özel kurulușların bir kısmı hukuka uygun yani meșru, diğer bir kısmı ise, hukuk dișidur; yani bunlara meșruiyet tanınmaz. Hukuka uygun kuruluşlar, devlet tarafından mevcudiyetlerine müsaade edilenlerdir; müsaade edilmeyenlerin hepsi hukuk dișıdır.

(99) Leviathan... Sf. : 140. .

(100) Leviathan... Sf. : 146.

A. Huk. F. Der. 
Politik kurulușlarda yani siyasî müesseselerde, temsil selâhiyeti sinırlandırılmıștır; bu sinırlandırmayı yapan hükümran kudrettir. Sinırlandırma lâzımdur; çünküi sınırlandırılmamıș tek kudret, hükümran kudrettir. Her devlette hükümran, bütün teb'anın mutlak temsilcisidir; ondan bașka hiçkimse, teb'anın bir kısmının dahi temsilcisi olduğunu iddia edemez. Bir devletde siyasî müesseselere sunırlandırılmamıș kudretler tanımak, daha doğrusu siyasî müesseselerin temsil yetkilerini sınırlandırmamak sulha ve müdafaa prensibine aykurıdır.

Politik kuruluşların temsil yetkisinin hudutlandırılması, iki șeyde tezahür eder: a-Hükümranin isdar ettiği emirlerde ve mektuplarında, b- Devlet hukukunda (Devlet hukukundan devlette cari kanuılar1 anlamak gerekir).

Siyasî kurulușlar, devlete nazaran tâli mahiyette kaldıkları ve hükümran kudrete tâbi bulundukları için, bunların karar ve tasarruflarını protesto etmek mümkündür. Meselâ temsilciler meclisinin kararlarına karșı bir kimse protestoda bulunabilir; fakat hükümran kudrete karşı böyle bir protestoda bulunmaya imkân yoktur (101).

Aile, hukuka uygun, nizamî ve özel kurulușlardan biridir. Hobbes, özel kurulușlarin da nizamî ve gayri nizamî nevilerini kabul etmektedir. Iște aile, hem, meșrû, özel ve hem de nizamî kurulușlara tipik bir örnektir. Özel kurulușlardan nizamî ve hukuka uygun olanlar, yazılı bir kanuna veya başkaca hükümran otoritenin tezahür șekline istinat etmezler; muteberiyetlerini Commen Law'dan alırlar.

Ailede bir șahsın temsilciliği altında toplanmıș bir birlik bahis konusudur; bu vasıfları yüzünden bu kurulușlar nizamî sayılırlar. Bü tün ailelerde, aileye dahil fertlerin hepsine, baba veya aile büyüğü emir ve kudanda eder. Baba, kanunların müsaade ettiği nisbette, aile efradının, çocuklarını, hizmetçilerini mükellefiyetlere tâbi kılar. Aile mensupları, aile çerçevesi içinde kalan bütün münasebet ve tasarruflarında babaya tâbidir; baba âdeta ailenin en yakın hükümranı (:= their immediate sovereign) dır. Öyleki devlet tesekkül etmeden evvel baba veya aile büyügü ailesi için mutlak mânada bir hükümran idi (102); mamafih devlet teșekkül ettikten sonra bile mutlak mânada bir kudret leaybına uğramamıștır.

(101) Leviathan... Sf. : 149.

(102) Leviathan... Sf. : 153-154. 
Bir de, nizamî ve özel olmakla beraber hukuk dışı kuruluşlar vardır (103) ; bunlar da bir șahsın temsilciliği altında toplanmıșlardır. Tabiî bu toplanıșta herhangi bir âmme otoritesinin mevcudiyeti düşünülemez. Bu kabil kuruluşlara örnek olarak, dilencilerin, hursızların ve çingenelerin, dilenmek ve hursızlık etmek yolundaki kazanç gayeleri ile teșkil ettikleri «corporation» lar zikredilebilir.

Gayri nizamî sistemler (kurulușlar), hususi veya mahsus bir niyet birliği olmaksızın meydana gelivermiș topluluklardan, veya bazan sadece halk kalabalıklarından ibarettir. Kaydedildiği gibi bunlarda bir niyet birliği yok fakat, arzu ve temayüllerde bir nevi ben zerlik vardır. Bu kuruluşlar, sisteme dahil her belirli kimsenin niyetinin hukuka uygun olup olmamasina göre, meșrû veya gayri meșrû olabilirler; bu, kalabalığın teșekküiü sebebine ve kalabalığı teșkil eden şahısların sayısına bağlıdır. Kalabalığın teșekkülü sebebi meșru veya hukukî ise, halk kalabalığı da meșru veya hukukî olur: Meselâ kilisedeki mûtad toplantılarda, bir müsamerede hazır bulunmada olduğu gibi.. Fakat kalabalığı teșkil eden fertlerin sayısı görülmemiș derecede fazla olursa, toplanmanin sebebi farkedilmez ve neticeden kalabalığa kapılan bir kimse, diğerlerinin arasında ne sebebten dolayı bulunmakta olduğunun muhasebesini yapmak imkânından mahrum kalır; böylece, bu kabil topluluk veya kalabalıkları, șuurlu bir șekilde gayri meșru addetmek gerekir. Bununla beraber, me selâ bin kișiden terekküp eden bir kalabalık da, bir hâkime veya majistraya dilekçe sunmak saiki ile bir araya gelmiş bulunuyorlarsa, hukukî veya meșrû olarak addolunabilir; yeterki bu bin kiși, böyle bir dilekçe sunmak niyetiyle bir araya gelmiș buluna... (104).

14. - HUKUMRAN KUDRE- Hobbes, Leviathan'm XXIII. «Chapter»ini TIN ÁMME TDERECILERT bu bahse tahsis etmiștir.

\section{A-) Ammeidarecilerikimlerdir?}

«Âmme idarecisi (Public Minister) devleti belli bir hizmet nevinde temsil etmek selâhiyeti ile, bir monark veya bir meclisten ibaret suveren tarafindan techiz kllıan ve böylece o hizmet nevinde istihdam edilen bir kimsedir (105).»

$\begin{array}{cccccc}(103) & \gg & \ldots & \gg & : & 154 . \\ (104) & \text { Leviathan } . . & \text { Sf. } & : & 155 \\ (105) & \gg & \ldots & \gg & : & 156 .\end{array}$




\section{B-) Genel yetkili âmme idarecileri.}

Âmme idarecilerinin bir lkısmı, ya ülkenin tamamı veya bir kısmı üzerinde cari olmak üzere, genel yetki ile techiz edilmiș durumda bulunabilirler. Meselâ, ülkenin tàmamı nazara alınmak üzere, küçük kralın babası tarafından, krallığın küllî idaresi için, kralın küçüklük çağma mahsur olmak üzere bir protektör veya naip tayin edilmis bulunabilir. Bu halde, teb'aya dahil her ferdin bu protektör veya naibe itaat etmek mecburiyeti, ve bu protektör veya naibin de, kral adına tasarrufta bulunmak, karar ittihaz etmek hakkı vardır. 